\title{
MENUJU PELABUHAN BERKELANJUTAN TANPA INVESTASI
}

\section{TOWARDS SUSTAINABLE HARBOUR WITHOUT INVESTMENT}

\author{
Muhammad Haris ${ }^{* 1)}$, Teuku Yuri M. Zagloel ${ }^{2)}$, Raldi Hendro S. Koestoer 1) \\ 1) Program Studi Ilmu Lingkungan Universitas Indonesia, Jakarta \\ Fakultas Teknik Universitas Indonesia, Jakarta \\ ${ }^{*}$ E-mail: muhammad.haris31@ui.ac.id
}

\begin{abstract}
Abstrak
Persaingan antar pelabuhan khususnya di terminal peti kemas, mendesak pihak Terminal Peti Kemas Belawan (BICT) untuk meningkatkan kinerja operasional pelabuhan. Meningkatnya isu lingkungan seperti perubahan iklim dan konsumsi energi menjadikan pengelola pelabuhan harus merancang pengembangan pelabuhan berwawasan lingkungan yang berkelanjutan. Operasional terminal peti kemas mencakup tiga jenis peralatan bongkar muat, yaitu container crane (CC), Rubber Tyred Gantry Crane (RTGC) dan truk. Tingginya biaya investasi peralatan bongkar muat membuat pengelola pelabuhan menerapkan optimalisasi operasional menuju pelabuhan berwawasan lingkungan. Penelitian ini bertujuan untuk merekonstruksi kembali operasional dengan menggunakan metode penjadualan peralatan dan modified distribution pada penataan peti kemas. Hasil optimalisasi penelitian ini dapat mengurangi $44 \%$ effective time, konsumsi energi, efisiensi tenaga kerja dan efisiensi biaya logistik dengan peningkatan produktivitas menjadi $25 \mathrm{~B} / \mathrm{C} / \mathrm{H}$. Penelitian ini berkontribusi pada tataran teknis pengembangan pelabuhan berkelanjutan tanpa melakukan investasi.
\end{abstract}

Kata kunci: kinerja pelabuhan, modified distribution, optimalisasi, pelabuhan berkelanjutan, penjadualan

\begin{abstract}
Competition between ports, especially container terminal, urges Belawan International Container Terminal (BICT) to improve their operational performance. The environmental issues such as climate change and energy consumption have been increasing and they pushed port operator to design green seaport. The operation of container terminal includes three kinds of cargo handling equipments, which are container crane (CC), Rubber Tyred Gantry Crane (RTGC) and truck. The high cost investment on cargo handling equipments at container terminal has made port operator implement operational optimalization heading to green seaport. This research has a purpose of restructuring the operation by using cargo handling equipments scheduling and modified distribution method. The result of the optimalization research can improve effective time, energy consumption, human resource and logistic cost efficiency by $44 \%$ while also increasing productivity to $28 \mathrm{~B} / \mathrm{C} / \mathrm{H}$. This research contributes to the technical aspect of green seaport development without the need of any monetary investment.
\end{abstract}

Keyword: modified distribution, optimalization, port performance, schedulling, sustainable seaport

\section{PENDAHULUAN}

Permasalahan pembangunan yang dihadapi suatu negara selalu berubah dan kompleks seiring dengan bertambahnya tuntutan pembangunan. Kemampuan dan sumber daya untuk mendukung pembangunan terbatas. Sumber daya yang tersedia harus dioptimalkan untuk memenuhi tuntutan yang tidak terbatas dengan membuat skala prioritas rencana pembangunan. Salah satu upaya penyelesaian masalah pembanguan adalah pembangunan berkelanjutan. Menurut World Commission on Environment and Development, (1987) Gagasan pembangunan berkelanjutan yaitu memenuhi kebutuhan sekarang tanpa mengorbankan pemenuhan generasi masa depan. Kegiatan pembangunan ekonomi di Indonesia berbasis kepada sumber daya alam. Hal tersebut dapat menyebabkan permasalahan pada 
perlindungan dan pelestarian lingkungan. Menurut United Nation Environment Programme (UNEP), (2011) ekonomi hijau sebagai kegiatan perekonomian yang mampu meningkatkan kesejahteraan dan keadilan sosial di satu sisi, tetapi di sisi lain mampu menghilangkan dampak negatif pertumbuhan ekonomi pada lingkungan dan kelangkaan sumber daya alam.

Perdagangan di era globalisasi telah membawa perubahan dan berdampak pada perekonomian suatu negara. Intergrasi antar komponen distribusi yang baik dapat memperoleh sistem logistik yang efisien dan efektif untuk meningkatkan daya saing nasional. Berdasarkan data Logistic Performance Index (LPI) kinerja logistik Indonesia berada pada peringkat 63 dari 163 negara yang disurvey (The World Bank, 2016). Salah satu upaya pemerintah untuk peningkatan konektivitas melalui pembangunan infrastuktur laut. Pemerintah saat ini mengembangkan konsep tol laut untuk mendukung pertumbuhan ekonomi Indonesia. Menurut Prihartono (2013) Elemen tol laut terdiri atas pelabuhan yang handal, kecukupan muatan, inland akses yang efektif, industri pelayaran dan pelayaran rutin.

Saat ini pengelolaan pelabuhan di Indonesia belum optimal. Hal ini dapat dilihat pada kinerja operasional pelabuhan. Kinerja operasional pelabuhan dapat dipengaruhi oleh dwelling time. Presiden Republik Indonesia Joko Widodo menginginkan agar dwelling time di Indonesia maksimal tiga hari (http:m.tempo.co., 2016). Saat ini dwelling time di Belawan International Terminal Container (BICT) 6 (enam) hari untuk impor dan 3 (tiga) hari untuk ekspor, bahkan pada pemberitaan harian Kompas (2016) menurut Presiden Joko Widodo bahwa dwelling time Pelabuhan Belawan mencapai 7 sampai 8 hari. Inefisiensi pada operasional pelabuhan dapat mengakibatkan dampak negatif pada lingkungan untuk itu operasional pelabuhan harus mempunyai konsep pembangunan berkelanjutan.

Implementasi berkelanjutan pengembangan pelabuhan adalah pelabuhan berwawasan lingkungan (Green Seaport). Model pelabuhan berwawasan lingkungan (Green Seaport) menjadi orientasi pelabuhan di masa depan. Konsep Green Seaport adalah mengintegrasikan metode ramah lingkungan pada kegiatan, operasional, dan manajemen pelabuhan (Anastasopoulos et al., 2011). Langkah-langkah membangun pelabuhan ramah lingkungan adalah pengendalian emisi udara, polusi air laut, pengelolaan sampah, pengelolaan kebisingan, efisiensi energi, penggunaan energi terbarukan, dan pengelolaan sumberdaya (Taneja et al., 2012; Anastasopoulos et al., 2011; ESPO, 2012).

Berdasarkan penelitian-penelitian tersebut, topik permasalahan pelabuhan berwawasan lingkungan masih pada tataran strategi kebijakan pengembangan pelabuhan berwawasan lingkungan, efisiensi pelabuhan dengan cara investasi teknologi ramah lingkungan. Namun, pada tataran teknis penelitian tentang pelabuhan berwawasan lingkungan jumlahnya masih sedikit. Pada penelitian ini akan dilakukan optimalisasi operasional terminal peti kemas dengan cara penjadualan peralatan bongkar muat dan penataan peti kemas tanpa melakukan investasi peralatan bongkar muat.

Peningkatan sistem logistik yang efisien dapat dilakukan dengan optimalisasi operasional terminal peti kemas, sehingga operasional terminal harus efisien dan produktivitasnya optimal. Tujaun penelitian ini adalah Merencanakan pola optimalisasi operasional terminal peti kemas menuju pelabuhan berwawasan lingkungan di BICT.

Meningkatnya gelombang kesadaran dan kepedulian masyarakat pada lingkungan mempengaruhi pengelola pelabuhan untuk mewujudkan pelabuhan yang berwawasan lingkungan. Penelitian yang berkembang tentang pelabuhan berwawasan lingkungan menurut Taneja et al. (2012); Denktas-Sakar dan KaratasCetin (2012); Wiegmans dan Geerlings (2010), bahwa perencanaan pelabuhan berwawasan lingkungan harus konsisten dengan konsep pembangunan berkelanjutan sebagai berikut: a) 
Penggunaan ruang secara efisien; b) Penggunaan sumber daya secara efisien dan peningkatan produktivitas aset; c) Akses pelabuhan yang memadai; d) Meminimalisasi konsumsi energi; e) Pertimbangan investasi biaya pemulihan insfrastruktur pelabuhan; dan

Pengembangan teknologi pelabuhan yang ramah lingkungan.

Operasional terminal peti kemas tidak selamanya berjalan dengan baik. Tidak berjalannya sistem pada operasional akan berdampak pada ketidakteraturan/kemacetan operasional terminal. Dampak kemacetan akan membuat operasional terminal melambat. Kondisi ini disebabkan kelebihan beban pada lapangan penumpukan dan menyebarnya kemacetan di lapangan penumpukan. Menurut Vacca, et al. (2010) untuk mengurangi kemacetan di terminal peti kemas dapat dilakukan dengan pengelolaan sebagai berikut:

1) Alokasi dermaga dan penjadualan

2) Alokasi container crane dan penjadualan

3) Operasional pergerakan peti kemas (transfer operation)

4) Penyimpanan (Storage) dan penyusunan (stacking) peti kemas.

\section{Penjadualan}

Konsep dasar penjadualan terjadi akibat adanya permasalahan pada berbagai macam tugas atau proses yang harus dilakukan, sedangkan sumber daya (waktu, bahan baku, tenaga kerja, mesin, modal, dan sebagainya) yang dibutuhkan untuk menyelesaikan tugas-tugas atau proses tersebut terbatas. Penjadualan didefinisikan sebagai pengaturan waktu dari suatu kegiatan yang mencakup kegiatan mengalokasikan fasilitas, peralatan atau tenaga kerja bagi suatu kegiatan operasi dan menentukan urutan pelaksanaan kegiatan operasi (Baker et al., 2013).

Sistem penjadualan harus membentuk aktivitasaktivitas untuk memastikan suatu aliran kerja yang lancar pada tahap proses produksi. Menurut Morton et al. (2001) Penjadualan produksi memiliki beberapa fungsi pada sistem produksi yaitu: a. Loading (pembebanan) bertujuan koordinasi yang melibatkan antara kebutuhan yang diminta dengan kapasitas untuk mementukan fasilitas, operator dan peralatan.

b. Sequencing (penentuan urutan) bertujuan membuat prioritas urutan pengerjaan pada pemrosesan order-order yang masuk.

c. Dispatching (prioritas pekerjaan), bertujuan prioritas kerja tentang pekerjaan-pekerjaan mana yang diseleksi dan diprioritaskan untuk diproses.

d. Pengendalian kinerja penjadualan, bertujuan agar penjadualan dapat dilakukan dengan cara meninjau kembali status pesanan-pesanan pada saat melalui sistem tertentu. Pengendalian ini dapat berupa pengaturan kembali urutan-urutan pekerjaan dikarenakan hal-hal tertentu.

e. Updating schedule, pelaksanan jadual selalu ada masalah baru yang berbeda pada proses pembuatan jadual.

Metode penjadualan pada peralatan penanganan peti kemas sangat penting untuk peningkatan kinerja operasional terminal peti kemas. Menurut $\mathrm{Lu}$ et al. (2016) Pada metode penjadualan peralatan di terminal peti kemas ada beberapa hal yang harus diperhatikan yaitu:

1) Tata letak terminal dan jumlah peralatan bongkar muat.

2) Perencanaan pada tata letak peti kemas pada blok lapangan penumpukan.

3) Jadual waktu penanganan peti kemas sudah teridentifikasi khususnya pada kegiatan receiving-delivery.

4) Kontrol lalu lintas terminal peti kemas sudah tersedia.

\section{Transportasi}

Salah satu masalah yang dihadapi oleh perusahaan adalah menentukan cara yang tepat untuk mendistribusikan barang dengan cepat dan tepat serta biaya yang seminimal mungkin ke tempat distributor. Menurut Heizer dan Render (2005), Untuk menggunakan model transportasi kita harus mengetahui hal-hal berikut: 1) Titik asal dan kapasitas atau pasokan pada setiap periode. 2) Titik tujuan dan permintaan pada 
setiap periode, 3) Biaya pengiriman satu unit dari setiap titik asal ke setiap titik tujuan. Ada beberapa metode transportasi yang dapat digunakan untuk menyelesaiakan masalah transportasi. Pada penelitian ini metode yang digunakan adalah metode Modified Distribution (MODI). Metode MODI ini dapat juga dipergunakan untuk mencari solusi optimum.

Metode MODI biasanya digunakan untuk mencari solusi penghematan biaya distribusi barang serta dapat mencapai hasil optimal yang lebih cepat. Pada penelitian ini akan dilakukan penempatan peti kemas ke blok lapangan penumpukan dengan menggunakan prinsip distribusi barang. Penerapan metode MODI pada penelitian ini bertujuan untuk menentukan blok peti kemas dan pola pergerakan truk dari kapal ke lapangan punumpukan maupun sebaliknya sehingga distribusi peti kemas berjalan dengan efisien.

\section{GAMBARAN UMUM}

Pelabuhan Belawan adalah salah satu pelabuhan utama di Indonesia yang memiliki lokasi sangat strategis karena hanya berjarak tempuh $13,5 \mathrm{~km}$ dari jalur pelayaran internasional Selat Malaka (Gambar 1), Pelabuhan ini terletak di sebuah daratan semenanjung yang merupakan muara pertemuan dua sungai yaitu Belawan dan Deli. Secara geografis posisinya terletak pada $03^{0} 47^{\prime}$ 20" LU dan $98^{\circ} 42^{\prime} 08^{\prime}$ ' BT, sehingga secara administratif kewilayahan berada di pada Kecamatan Medan Belawan Pemerintah Kota Medan. Studi kasus Penelitian ini adalah terminal peti kemas di Pelabuhan Belawan, karena Terminal Peti Kemas Belawan atau BICT karena terminal peti kemas dapat memberikan dampak perekonomian dan salah satu pelabuhan utama di Indonesia. Lokasi Belawan International Container Terminal (BICT) dapat dilihat pada Gambar 1.

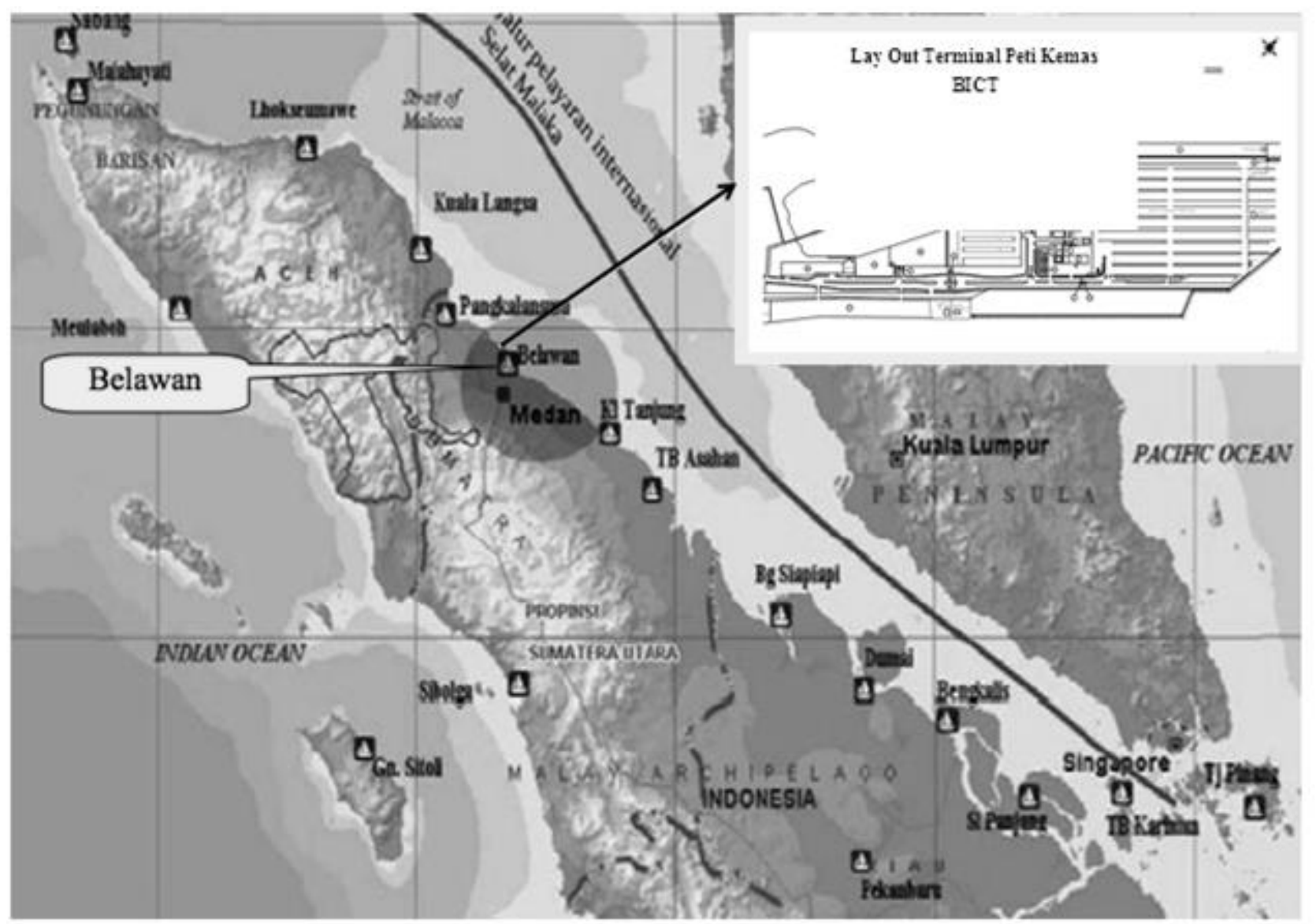

Gambar 1. Lokasi Belawan International Container Terminal (BICT)

(Sumber: Rencana Induk Pelabuhan Belawan, 2012) 


\section{HASIL DAN PEMBAHASAN}

Berdasarkan pengamatan lapangan, pada pada jam sibuk (15.00-22.00 WIB) terjadi penurunan produktivitas pelabuhan. Hal ini dikarenakan: 1) Jumlah peralatan pada lapangan penumpukan terbatas yaitu RTGC. Pada alat RTGC harus melayani proses receiving-delivery dan eksporimpor. 2) Penanganan proses receiving-delivery belum terjadual dengan baik sehingga pada jamjam tertentu terjadi antrian pelayanan. 3) Antrian truk yang menunggu giliran untuk proses receiving-delivery mempengaruhi kelancaran lalu lintas di lapangan penumpukan. Adanya masalah-masalah tersebut diperlukan suatu alternatif dari penjadualan produksi dengan menggunakan teknik pengurutan (sequencing) dan model penataan peti kemas di lapangan penumpukan.

\section{Penjadualan Peralatan Bongkar Muat}

Model penjadualan pada penelitian ini terdiri dari dua macam alternatif teknik pengurutan pesanan, yaitu berdasarkan Shortest Processing Time (SPT) dan Longest Processing Time (LPT). Metode tersebut akan menghitung waktu alir rata-rata dan rata-rata keterlambatan pada peralatan RTGC disetiap periode penjadualan. Penjadualan yang dilakukan mengakomodir lama waktu penjadualan tahap bongkar muat dan receiving-delivery yang di masukan ke model berdasarkan kondisi nyata di lapangan.

Asumsi yang digunakan pada pengembangan metode penjadualan peralatan bongkar muat di Terminal Peti Kemas BICT sebagai berikut:

1) Keseluruhan peralatan bongkar muat siap memproses peti kemas.

2) Pada kegiatan receiving-delivery sudah memiliki jadual peti kemas masuk dan keluar lapangan penumpukan.

3) Kegiatan operasional terminal peti kemas berlangsung selama 24 jam dalam 7 hari.

4) Dwelling time peti kemas maksimal 2 hari.

5) Setiap pekerjaan pada peralatan bongkar muat yang sedang berlangsung tidak boleh di interupsi.
6) Berdasarkan data siklus pergerakan peti kemas, observasi, dan produktivitas maka siklus kinerja per alat minimal 135 Box/detik.

7) Kecepatan truk di kawasan pelabuhan dibatasi pada $20 \mathrm{~km} / \mathrm{jam}$. Metode penjadualan ini membuat alternatif pola optimalisasi operasional pada lapangan penumpukan.

Hasil penjadualan akan dihitung rata-rata waktu penyelesaian pekerjaan (MFT) dan rata-rata keterlambatan (ML) untuk tiap-tiap peralatan serta banyaknya jumlah pekerjaan yang terlambat. Berikut akan ditampilkan hasil dari perhitungan MFT (Mean Flow Time) dan ML (Mean Lateness) dari kedua aturan pengurutan yaitu SPT dan LPT dapat dilihat pada Tabel 1.

Tabel 1 Perhitungan MFT dan ML serta jumlah pekerjaan yang terlambat

\begin{tabular}{lrrrr}
\hline & \multicolumn{2}{c}{ SPT } & \multicolumn{2}{c}{ LPT } \\
\cline { 2 - 5 } Alat & \multicolumn{3}{c}{ M } & \multicolumn{2}{c}{ M } \\
& MFT & L & MFT & L \\
\hline RTGC 1 & 5,06 & - & 6,58 & - \\
RTGC 2 & 5,06 & - & 6,58 & - \\
RTGC 3 & 5,09 & - & 6,58 & - \\
RTGC 4 & 5,09 & - & 10,18 & - \\
RTGC 5 & 20,55 & - & 10,12 & - \\
Rata-rata & 6,14 & - & 5,29 & - \\
Banyak & & & & \\
Pekerjaan & & & & \\
terlambat & - & & & \\
Sulber Hasil Peray
\end{tabular}

Sumber: Hasil Perhitungan

Pada Tabel 1. dapat dilihat perbandingan antara aturan SPT dan LPT. Perhitungan waktu penyelesaian pekerjaan pada saat kegiatan ekspor-impor dengan menggunakan aturan LPT didapat rata-rata waktu penyelesaian pekerjaan untuk seluruh peralatan bongkar muat adalah 5,29 Jam. Pada optimalisasi aturan penjadualan ini tidak terjadi keterlambatan seluruh peralatan bongkar muat. Optimalisasi yang akan digunakan pada operasional terminal peti kemas adalah metode LPT. Hal ini karena rata-rata waktu penanganan peti kemas metode SPT lebih besar dari pada metode SPT sehingga kapal cepat 
keluar dari pelabuhan dan peningkatan produktivitas pelabuhan. Manfaat meminimasi kelambatan rata-rata adalah berkurangnya waktu menunggu rata-rata, sehingga dapat meminimasi rata-rata jumlah pekerjaan yang menunggu dalam antrian.

Pada sistem ini terjadi peningkatan utilisasi RTGC dari $40 \%$ menjadi $60 \%$. Hasil penjadualan alat akan dijadikan dasar pada metode penataan peti kemas. Berdasarkan aturan penjadualan dapat diketahui kombinasi peralatan dan letak peralatan bongkar muat dengan jumlah peralatan 4 CC : 6 RTGC : 12 truk dan masing-masing 1 RTGC untuk kegiatan receiving-delivery.

\section{Penataan Peti Kemas Di Lapangan Penumpukan}

Salah satu cara meningkatkan efisiensi pelabuhan adalah mengurangi waktu bongkar muat dengan penataan dengan sebaik mungkin peti kemas di lapangan penumpukan. Lokasi peti kemas yang telah ditentukan dapat membantu penjadualan RTGC dan truk pengangkut peti kemas. Peralatan RTGC berfungsi untuk mengambil peti kemas dari lapangan kemudian diletakkan di atas truk. Rute dan urutan pengambilan peti kemas dapat dilakukan setelah lokasi peti kemas ditentukan sehingga pemindahan peti kemas dari lapangan penumpukan menuju dermaga dapat berjalan dengan lancar.

Penentuan lokasi peti kemas ini akan menggunakan metode modified distribution (MODI). Salah satu indikator pelabuhan yang efisien adalah waktu tinggal peti kemas di Pelabuhan singkat. Pada penelitian waktu tinggal peti kemas diasumsikan 2 hari. Ketersediaan peralatan bongkar muat menjadi dasar penentuan waktu tinggal peti kemas. Analisis tata letak pelabuhan dengan menggunakan metode MODI akan dibagi menjadi 2 perhitungan yaitu tata letak penempatan pada blok D-E-F dan blok GH-I. Berikut hasil perhitungan tata letak peti kemas pada blok D-E-F.

Tabel 2. Tata Letak Peti Kemas Impor Pada Lapangan Penumpukan Blok D-E-F

\begin{tabular}{|c|c|c|c|c|c|}
\hline \multirow{2}{*}{ Dermaga } & \multirow{2}{*}{\multicolumn{2}{|c|}{ Traffik (TEUs) }} & \multicolumn{3}{|c|}{ Blok Lapangan Penumpukan } \\
\hline & & & $\mathrm{D}$ & $\mathrm{E}$ & $\mathrm{F}$ \\
\hline \multirow{2}{*}{1} & \multirow{2}{*}{ Impor } & \multirow{2}{*}{373} & 732 & 751 & 856 \\
\hline & & & $4, \overline{10}$ & 9,81 & \\
\hline \multirow{2}{*}{2} & \multirow{2}{*}{ Impor } & \multirow{2}{*}{373} & 762 & 781 & 886 \\
\hline & & & & 4,37 & $\mathbf{1 , 5 7}$ \\
\hline
\end{tabular}

Sumber: Hasil Perhitungan

Berdasarkan Tabel 2. waktu yang dibutuhkan untuk melakukan kegiatan bongkar peti kemas impor adalah 29,85 jam. Penempatan peti kemas pada blok tersebut akan dilakukan optimalisasi dengan melakukan perhitungan metode MODI.

a) Menentukan nilai $u_{i} d a n v_{j}$

\begin{tabular}{llll}
\hline Sel 1-D: & $\mathrm{u}_{1}-\mathrm{v}_{\mathrm{D}}=\mathrm{c}_{1 \mathrm{D}}$ & $0-\mathrm{v}_{\mathrm{D}}=732$ & $\mathrm{v}_{\mathrm{D}}=732$ \\
Sel 1-E: & $\mathrm{u}_{1}-\mathrm{v}_{\mathrm{E}}=\mathrm{c}_{1 \mathrm{E}}$ & $0-\mathrm{v}_{\mathrm{E}}=751$ & $\mathrm{v}_{\mathrm{E}}=751$ \\
Sel 2-E: & $\mathrm{u}_{2}-\mathrm{v}_{\mathrm{E}}=\mathrm{c}_{1 \mathrm{D}}$ & $\mathrm{u}_{2}-\mathrm{v}_{\mathrm{E}}=781$ & $\mathrm{u}_{2}=30$ \\
Sel 2-F: & $\mathrm{u}_{2}-\mathrm{v}_{\mathrm{F}}=\mathrm{c}_{2 \mathrm{~F}}$ & $\mathrm{u}_{2}-\mathrm{v}_{\mathrm{F}}=886$ & $\mathrm{v}_{\mathrm{F}}=856$ \\
\hline
\end{tabular}

b) Menentukan indeks perbaikan

\begin{tabular}{ll}
\hline Sel Kosong & Indeks Perbaikan \\
Sel 1 - F & $856-0-856=0$ \\
Sel 2 - D & $762-30-732=0$ \\
\hline
\end{tabular}

Berdasarkan pada perhitungan tersebut nilai pada sel 1-F dan 2 - D sudah menunjukkan nilai positif. Nilai positif tersebut dapat disimpulkan peletakan peti kemas impor pada blok D-E-F sudah optimal. Hasil perhitungan tata letak peti kemas impor pada lapangan penumpukan blok G-H-I akan disampaikan secara detail pada Tabel 3. 
Tabel 3. Tata Letak Peti Kemas Impor Pada Lapangan Penumpukan Blok G-H-I

\begin{tabular}{|c|c|c|c|c|c|c|c|c|}
\hline \multirow{2}{*}{ Dermaga } & \multirow{2}{*}{\multicolumn{2}{|c|}{ Traffik (TEUs) }} & \multicolumn{6}{|c|}{ Blok Lapangan Penumpukan } \\
\hline & & & & & & $\mathrm{H}$ & & [ \\
\hline \multirow{2}{*}{1} & \multirow{2}{*}{ Impor } & \multirow{2}{*}{373} & & 875 & \multirow[b]{2}{*}{12,62} & 967 & & 986 \\
\hline & & & 4,90 & & & & & \\
\hline \multirow{2}{*}{2} & \multirow{2}{*}{ Impor } & \multirow{2}{*}{373} & & 905 & & 997 & \multirow[b]{2}{*}{13,26} & 1016 \\
\hline & & & & & 5,58 & & & \\
\hline
\end{tabular}

Sumber: Hasil Perhitungan

Berdasarkan Tabel 3 waktu yang dibutuhkan untuk melakukan kegiatan bongkar peti kemas impor adalah 36,36 jam. Penempatan peti kemas pada blok tersebut akan dilakukan optimalisasi dengan melakukan perhitungan metode MODI.

1. Menentukan nilai ui dan vj

\begin{tabular}{llll}
\hline Sel 1-D: & $\mathrm{u}_{1}-\mathrm{v}_{\mathrm{D}}=\mathrm{c}_{1 \mathrm{D}}$ & $0-\mathrm{v}_{\mathrm{D}}=875$ & $\mathrm{v}_{\mathrm{D}}=875$ \\
Sel 1-E: & $\mathrm{u}_{1}-\mathrm{v}_{\mathrm{E}}=\mathrm{c}_{1 \mathrm{E}}$ & $0-\mathrm{v}_{\mathrm{E}}=967$ & $\mathrm{v}_{\mathrm{E}}=967$ \\
Sel 2-E: & $\mathrm{u}_{2}-\mathrm{v}_{\mathrm{E}}=\mathrm{c}_{1 \mathrm{D}}$ & $\mathrm{u}_{2}-\mathrm{v}_{\mathrm{E}}=997$ & $\mathrm{u}_{2}=30$ \\
Sel 2-F: & $\mathrm{u}_{2}-\mathrm{v}_{\mathrm{F}}=\mathrm{c}_{2 \mathrm{~F}}$ & $\mathrm{u}_{2}-\mathrm{v}_{\mathrm{F}}=1016$ & $\mathrm{v}_{\mathrm{F}}=986$ \\
\hline
\end{tabular}

2. Menentukan indeks perbaikan

\begin{tabular}{ll}
\hline Sel Kosong & Indeks Perbaikan \\
Sel 1 - F & $986-0-986=0$ \\
Sel 2 - D & $905-30-875=0$ \\
\hline
\end{tabular}

Berdasarkan pada perhitungan tersebut nilai pada sel 1-F dan 2 - D sudah menunjukkan nilai positif. Nilai positif tersebut dapat disimpulkan peletakan peti kemas impor pada blok D-E-F sudah optimal.

Pada hasil metode MODI tersebut rata-rata jarak tempuh truk adalah $0,58 \mathrm{~km}$ untuk kegaiatan ekspor dan $0,75 \mathrm{~km}$ pada kegiatan impor. Peningkatan produktivitas terminal peti kemas bisa berhasil jika peralatan pada lapangan penumpukan dapat mendukung operasional di dermaga. Peningkatan produktivitas menjadi 25 $\mathrm{B} / \mathrm{C} / \mathrm{H}$ membutuhkan siklus pergerakan container crane adalah 2,4 menit, untuk mendukung peningkatan tersebut siklus pada pergerakan RTGC dan truk minimal sama dengan siklus Container Crane. Berdasarkan perhitungan metode MODI waktu tempuh/siklus pergerakan truk untuk kegiatan ekspor adalah 1,74 menit dan 2,4 menit untuk kegaiatan impor sehingga jumlah truk yang dibutuhkan untuk kelancaran siklus container crane adalah 3 truk. Untuk lebih jelas dapat dilihat Gambar 2. Tata Letak Peti Kemas dan Optimalisasi rute jalur truk.

Berdasarkan hasil optimalisasi opersional dengan menggunakan metode penjadualan dan tata letak peti kemas dapat meningkatkan produktivitas pelabuhan dengan kombinasi jumlah peralatan $2 \mathrm{CC}: 3 \mathrm{RTGC}: 6$ truk untuk setiap tambatan. Terminal Peti Kemas BICT terdiri atas 2 Tambatan sehingga total peralatan yang dibutuhkan untuk operasional terminal peti kemas dengan produktivitas $25 \mathrm{~B} / \mathrm{C} / \mathrm{H}$ adalah 4 Container Craner, 6 RTGC dan 12 truk. Jumlah peralatan bongkar muat masih mencukupi dari kondisi saat ini sehingga pengelola Terminal Peti Kemas BICT tidak perlu investasi alat baru.

\section{Hasil Penjadualan Dan Penataan Peti Kemas}

Berdasarkan hasil penjadualan peralatan RTGC dan penataan peti kemas di lapangan penumpukan dapat diketahui efisiensi waktu kerja di pelabuhan 12 jam dan produktivitas pelabuhan meningkat menjadi $28 \mathrm{~B} / \mathrm{C} / \mathrm{H}$, hal ini sesuai dengan teori Kemme (2013) dan UNCTAD (1988). Optimalisasi pada kinerja terminal peti kemas BICT dapat dilakukan dengan mengefisiensikan kinerja peralatan dan fasilitas yang dimiliki saat ini tanpa harus melakukan investasi baru pada fasilitas dan peralatan yang ada. Efisiensi kinerja peralatan yang dimiliki dapat dilakukan dengan meningkatkan produktivitas dari peralatan penanganan bongkar muat peti kemas serta Menurut Goodchild dan Daganzo, (2005) Efisiensi berthing time mempengaruhi jumlah penggunaan bahan bakar pada alat bongkar muat. Hasil Optimalisasi dapt dilihat pada Tabel 4. 


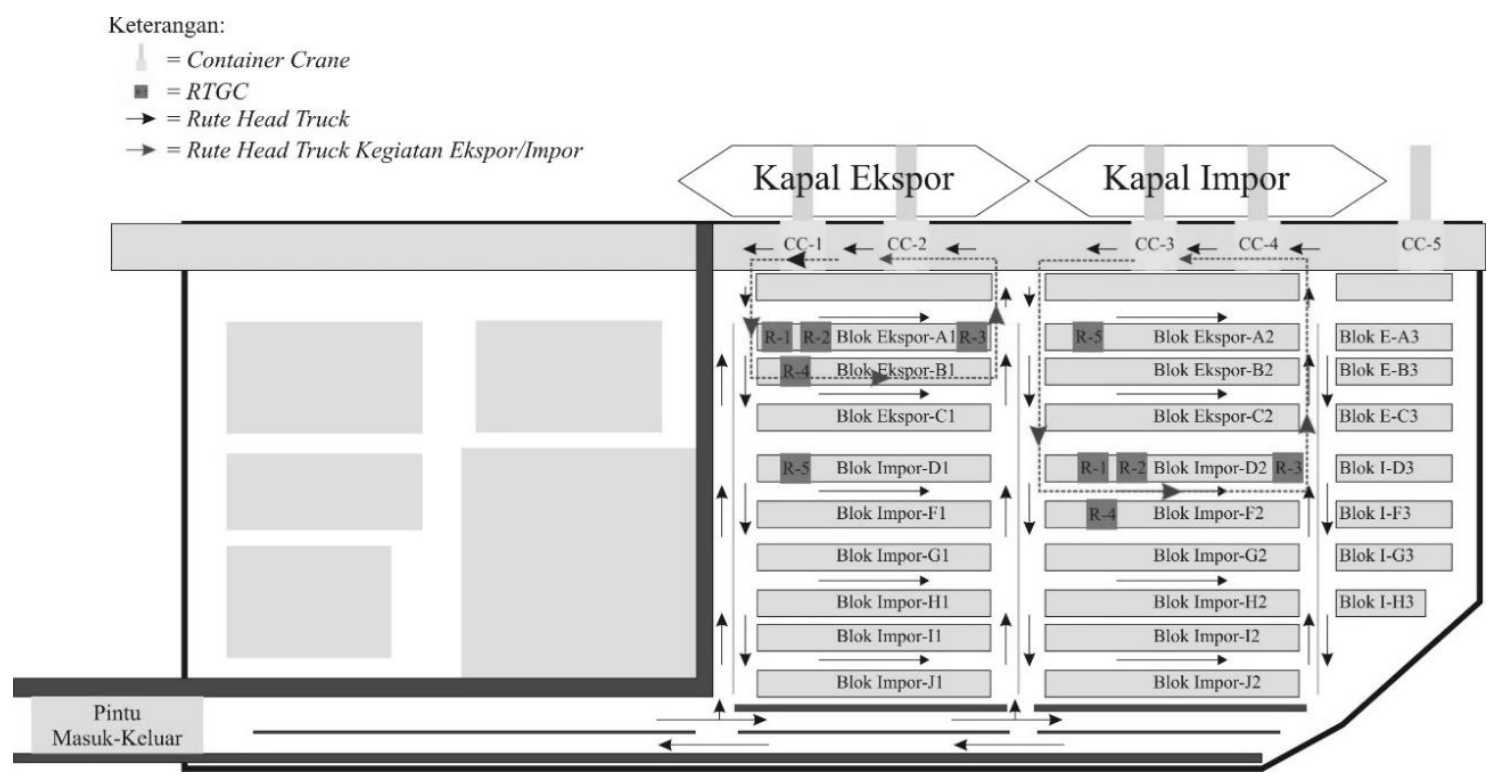

Gambar 2. Tata Letak Peralatan dan Optimalisasi Rute Jalur Truk

Tabel 4. Perbandingan Kinerja Pelabuhan Kondisi Saat Ini dan Usulan Perbaikan

\begin{tabular}{|c|c|c|c|c|}
\hline \multirow[b]{2}{*}{$\begin{array}{l}\mathrm{NO} \\
.\end{array}$} & \multirow[b]{2}{*}{ U R A I A N } & \multirow[b]{2}{*}{ SATUAN } & \multicolumn{2}{|c|}{ Kinerja Pelabuhan } \\
\hline & & & Saat ini & $\begin{array}{l}\text { Usulan } \\
\text { Perbaikan }\end{array}$ \\
\hline \multirow[t]{2}{*}{ A. } & Kunjungan Kapal & Call & 503 & 503 \\
\hline & Rata-Rata Box per Kapal & Box/Kpl & 693,53 & 693,53 \\
\hline \multirow[t]{13}{*}{ B. } & Service Time & & & \\
\hline & 1. Waiting Time (WT) & $\mathrm{Jam} / \mathrm{Kpl}$ & 1,58 & 1,58 \\
\hline & a. WT Berth & $\mathrm{Jam} / \mathrm{Kpl}$ & 0,52 & 0,52 \\
\hline & b. WT Pilot & $\mathrm{Jam} / \mathrm{Kpl}$ & 1,15 & 1,15 \\
\hline & 2. Approach Time (AT) & $\mathrm{Jam} / \mathrm{Kpl}$ & 2,22 & 2,22 \\
\hline & 3. Berthing Time (BT) & $\mathrm{Jam} / \mathrm{Kpl}$ & 27,76 & 15,58 \\
\hline & a. Berth Working Time (BWT) & $\mathrm{Jam} / \mathrm{Kpl}$ & 21,31 & 8,28 \\
\hline & Idle Time (IT) & $\mathrm{Jam} / \mathrm{Kpl}$ & 1,78 & 1,78 \\
\hline & Efective Time (ET) & $\mathrm{Jam} / \mathrm{Kpl}$ & 18,68 & 6,5 \\
\hline & b. Non Operating Time (NOT) & $\mathrm{Jam} / \mathrm{Kpl}$ & 7,3 & 7,3 \\
\hline & 4. Turn Round Time (TRT) & $\mathrm{Jam} / \mathrm{Kpl}$ & 31,56 & 19,38 \\
\hline & Turn Round Time ( TRT ) & Hari/Kpl & 1,32 & 0,8 \\
\hline & 5. ET/BT & $\%$ & $67,26 \%$ & $42 \%$ \\
\hline
\end{tabular}

Sumber: Hasil Perhitungan

Pada penelitian ini membahas perencanaan pola optimalisasi terminal peti kemas menuju pelabuhan yang berwawasan lingkungan. Sejalan dengan teori optimalisasi UNCTAD (1988) yang bertujuan untuk meningkatkan kinerja peralatan bongkar muat, operasional terminal sehingga dapat mewujudkan produktivitas yang terbesar, keuntungan terbesar, biaya yang minimal, penggunaan energi yang paling sedikit, dan sistem operasional yang efisien. Optimalisasi terminal peti kemas akan memberikan dampak pada lingkungan, organisasi dan ekonomi.

\section{Dampak Lingkungan}

Efisiensi berthing time dapat mengurangi potensi ceceran minyak dan pembuangan air balas yang akan mempengaruhi cemaran air laut. Pada tahun 2015 penggunaan rata-rata BBM jenis solar sebesar 60 liter/jam pada container crane dan 20 
liter/jam pada RTGC. Penggunaan mesin diesel pada peralatan bongkar muat dapat meningkatkan dampak negatif lingkungan. Dampak yang terjadi akibat penggunaan mesin diesel adalah kebisingan pada mesin, emisi gas buang pada saat beroperasi, dan kesehatan fisik pekerja terminal peti kemas. Hasil optimalisasi pada waktu efektif untuk bongkar muat peti kemas, semakin singkat waktu sandar kapal akan mempengaruhi konsumsi bahan bakar, emisi yang dihasilkan kapal pada saat mesin idle, emisi yang dihasilkan truk pada saat idle menunggu pelayanan bongkar muat.

Dampak langsung optimalisasi operasional adalah efisiensi energi. Efisiensi energi menjadi kunci menuju masa depan energi dan ekonomi berkelanjutan. Efisiensi energi berarti mengurangi laju pertumbuhan konsumsi energi dan menghindari penggunaan peralatan energi yang tidak dibutuhkan. Konsumsi berlebihan dan tidak efisien berkontribusi pada masalah lingkungan lokal, regional maupun global. Pada tingkat lokal, polusi udara dan partikulat menimbulkan masalah kesehatan. Tingkat regional, berkontribusi pada hujan asam. Tingkat global, penggunaan bahan bakar fosil berlebihan meningkatkan faktor perubahan iklim yaitu meningkatnya suhu, naiknya permukaan laut, dan cuaca ekstrim (badai, banjir, peningkatan sedimen, dan angin). Implikasi dampak potensial dari peningkatan faktor perubahan iklim akan mempengaruhi rute pelayaran baru, kerusakan pada infrastruktur pelabuhan, peningkatan biaya perawatan infrastruktur. Adaptasi yang dapat dilakukan untuk peningkatan kinerja pelabuhan adalah peningkatan infrastruktur, optimalisasi operasional, efisiensi manajemen, dan penggunaan teknologi yang ramah lingkungan.

\section{Dampak Sosial Organisasi}

Hasil optimalisasi operasional dapat dilaksanakan jika semua elemen baik pada tataran perencanaan, teknis, operasional dan sumber daya manusia harus sejalan. Pekerja yang berkerja pada operasional terminal peti kemas harus berada pada 1 manajemen. Hal ini bertujuan agar pencapaian kinerja operasional dalam satu pengawasan. Selain itu, optimalisasi dapat miningkatkan efisiensi jumlah tenaga kerja.

Efisiensi jumlah tenaga kerja dapat dilakukan dengan memindahkan tenaga kerja ke tempat baru yang lebih produktif bukan pengurangan tenaga kerja. Selain itu untuk peningkatan kinerja diperlukan peningkatan kapasitas tenaga kerja. Peningakatan kapasitas tenaga kerja dapat dilakukan dengan pelatihan, benchmark ke pelabuhan yang memiliki kinerja operasional yang baik. Setelah peningkatan kapasitas tenaga kerja, manajemen pelabuhan dapat meingkatkan fungsi dan tanggung jawab pada job description yang sudah dibentuk sehingga sistem organisasi yang ideal menurut Prasetyo dan Wahyuddin (2004) dapat dilaksanakan.

\section{Dampak Ekonomi}

Optimalisasi perlu dilakukan untuk menyingkat durasi kegiatan bongkar muat dengan pengeluaran biaya seminimal mungkin sehingga target produktivitas dapat tercapai. Produktivitas dapat digambarkan pada dua pengertian yaitu secara teknis dan finansial. Pengertian produktivitas secara teknis adalah pengefesiensian produksi terutama dalam pemakaian ilmu dan teknologi. Sedangkan pengertian produktivitas secara finansial adalah pengukuran produktivitas atas output dan input yang telah dikuantifikasi. Mahalnya harga barang yang dipicu oleh tingginya biaya logistik, disebabkan oleh inefisiensi dan rendahnya produktifitas di pelabuhan. Salah satu penyelesaian masalah tersebut bukanlah dengan membangun lebih panjang dermaga atau membangun pelabuhan-pelabuhan di banyak tempat. Tapi yang dibutuhkan adalah alat kerja, crane, dan pendukung lainnya supaya dapat membongkar-muat barang atau container dengan cepat. Dengan produktifitas tinggi, tak akan ada kapal antre 3-4 hari. Utilitas tinggi, juga menurunkan ongkos transportasinya.

Hasil optimalisasi memberikan dampak positif pada efisiensi biaya yang dikeluarkan pemilik barang sebesar $61 \%$ /hari dan peningkatan rasio pendapatan operasional terminal. Hal ini dipengaruhi dwelling time peti kemas di 
pelabuhan menjadi 2 hari sehingga pemilik barang tidak dikenakan masa 1 (3 Hari) dari biaya penumpukan peti kemas di lapangan penumpukan. Sedangkan pendapatan yang dihasilkan setelah dilakukan optimalisasi adalah Rp. 1.030.960.000,-/ 15,58 jam. Efisiensi pelabuhan akan mempengaruhi biaya pelabuhan (baik biaya tetap maupun biaya tidak tetap) dan biaya kapal di pelabuhan (baik biaya waktu tunggu kapal maupun biaya waktu kapal di dermaga)

\section{KESIMPULAN}

Berdasarkan hasil optimalisai operasional pelabuhan, pengelola pelabuhan dapat melakukan efisiensi energi tanpa melakukan investasi. Merekonstruksi kembali sistem operasional terminal peti kemas akan mempengaruhi dampak positif 3 pilar keberlanjutan yaitu lingkungan, sosial, dan ekonomi. Optimalisasi operasional terminal peti kemas dilakukan dengan metode penjadualan dan Modified Distribution (Modi). Pada proses penjadualan Ekspor dan Impor yang paling efisien dilakukan dengan sistem LPT. Kombinasi peralatan bongkar muat 4 CC : 6 RTGC : 12 truk. Dampak optimalisasi operasional dapat mempersingkat berthing time (waktu kerja kapal) di pelabuhan sebesar 12,18 jam/kapal. Selain itu, Optimalisasi operasional dengan metode ini dapat memberikan dampak pada: a) Aspek lingkungan, mereduksi $44 \%$ penggunaan energi BBM dan mereduksi emisi pada peralatan bongkar muat; b) Aspek sosial, efisiensi jumlah tenaga kerja, Tenaga kerja pada operasioal harus berada 1 manajemen, sinkronisasi jam kerja operasional dan administrasi perijinan dengan implementasi national single window. c) Aspek ekonomi efisiensi biaya penumpukan sebesar $61 \%$ perhari ; serta pencapaian produktivitas 28 $\mathrm{B} / \mathrm{C} / \mathrm{H}$.

\section{DAFTAR PUSTAKA}

Anastasopoulos, D., Kolios, S., \& Stylios, C. (2011). How will Greek ports become Green ports Geo-Eco-Marina. Greece.
Baker, K. R., \& Trietsch, D. (2013). Principles of sequencing and scheduling. John Wiley \& Sons., Inc, Inc.

Denktas-Sakar, G., \& Karatas-Cetin, C. (2012). Port sustainability and stakeholder management in supply chains: A framework on resource dependence theory. The Asian Journal of Shipping and Logistics.

European Sea Port Organisation (ESPO). (2012). Green Guide: Towards Excellence in Port environmental Management and Sustainability. European Seaport Organisation (ESPO), Brussels, Belgium.

Goodchild, A., V., and C., F. Daganzo. (2005). Crane Double Cycling in Container Ports: Affect on Ship Dwell Time, Institute of Transportation Studies (University of California). Berkeley.

Heizer, Jay and Render, B. (2005). Operation Management (Manajemen Operasi) Edisi Ketujuh. Penerbit Salemba. Jakarta.

Kemme. (2013). Design and operation of Automated Container Storage System. Contribution to management Science. Berlin.

Lu, Y., Huang, Y., \& Yang, B. (2016). The Integrated Optimization of Quay CraneYard Truck Scheduling in the Container Terminal with Uncertain Factors. International Journal of Hybrid Information Technology.

Morton, T. E., \& Pentico, David W. (2001). Heuristic Scheduling Systems. Canada: John Wiley \& Sons, Inc.

Prihartono, B. (2013). Paparan Pengembangan Tol Laut Dalam RPJMN 2015-2019 Dan Implementasi 2015. Badan Perencanaan Pembangunan Nasional (Bappenas). Jakarta. 
PT Pelabuhan Indonesia I (Persero). (2012). Rencana Induk Pelabuhan Belawan. Medan.

Taneja, P., Vellinga, T. \& Ros, R. (2012). Role of Flexibility in Sustainable Port Development. Third International Engineering System Symposium. Delft University of Technology. Netherland.

The World Bank. (2016). Connecting To Compete 2016 Trade Logistics In The Global Economy. The Logistics Performance Index and Its Indicators. Washington, DC.

United Nations Conference on Trade and Development (UNCTAD). (1988). Operating and Maintenance Features of Container Handling System. Geneva. United Nations.

United Nations Environment Programme (UNEP). (2011). Towards A Green Economy. Pathways to Sustainable Development and Poverty Eradication. France.
Vacca, I., Salani, M., \& Bierlaire, M. (2010). Optimization of operations in container terminals: hierarchical vs integrated approaches. In 10th Swiss Transport Research Conference.

Wiegmans, B. W., and Geerlings, H. (2010). Sustainable Port Innovations: Barriers And Enablers For Successful Implementation. J. of World Review Intermodal Transportation Research.

World Commission on Environment and Development (WCED). (1987). Our Common Future, Oxford University. Press, New York.

https://m.tempo.co/read/news/2016/03/18/09075 5015/jokowi-ancam-reshuffle-targetdwelling-time-jadi-2-5-hari diakses 27 $\underline{\text { maret } 2016 .}$

http://nasional.kompas.com/read/2016/09/13/12 304531/jokowi.marah.dwelling.time.pelab uhan.belawan.masih.7.hingga.8.hari diakses 13 September 2016 